\title{
Clinical Regional Lymph Nodes TNM Finding
}

National Cancer Institute

\section{Source}

National Cancer Institute. Clinical Regional Lymph Nodes TNM Finding. NCI Thesaurus.

Code C162609.

A clinical finding about one or more characteristics of a specific cancer, following the rules of the TNM classification system as they pertain to staging of regional lymph nodes. 